\title{
Marginalized Selfhood of Women in Tehmina Durrani's Blasphemy
}

Dhobi Saleem, $\mathrm{PhD}$

\begin{abstract}
This paper investigates into Durrani's Blasphemy to scrutinize Heer's marginalized individuality. Heer is forced to marry a man, Pir Sain, with a high position in the society. Her marriage proves a source of troubles and repression of self-satisfaction. When Heer fails to tolerate severe torture and exploitation, she revolts against patriarchy that pushes the female sex to the margin in the name of religious norms and values. Hence, this article exposes the desperate condition of women and their sufferings in Pakistan as depicted in the novel. The paper questions the system that does not allow women like Heer to make decisions in either household chore, not in the public affairs.
\end{abstract}

Key Words: Exploitation, Islam, marginality, protest, religion, selfhood, sexual abuse

\section{Introduction}

The paper explores Durrani's Blasphemy to demonstrate the de-centered selfhood of Heer, the female protagonist. The novel exposes the world of a Muslim Pir Sain, Heer's husband. My argument is that the identity of women in Pakistan as portrayed in the novel is constructed and their rights are curtailed in comparison to those of men. Heer, a typical character, represents Pakistani women in general who suffer isolation, sexual abuse, and religious hypocrisy. The research foregrounds problems of seclusion, closeting, and veiling, and interrogates domestic abuse carried on under the religious hypocrisy. The struggle of Heer in the male-dominated society questions the democratic principles of Pakistan.

\section{Analysis}

The article demonstrates the dominance of Islamic values in the conjugal life of Heer and Pir Sain. Islamic system forces her to subdue her thoughts and freedom to choicein the world of religious hypocrisies. Besides, she has not been able to respect her personal values and desires since her childhood first as a daughter, secondly as a wife and finally as a mother. She suffers identity crisis in both personal and marital affairs. Pakistani society guided by the Islamic laws constructs the role of women and subjugates them in both private and public spaces. This subjugation does not allow women like Heer to lead an independent life. Rather she abides by the dictates of the society, serves her husband, Pir Sain, and endures all pains. Nevertheless, the fictional world is not exactly that in Pakistan 
everywhere. The revolting spirit of Heer elevates her position a step towards modernizing women in the Islamic society that presumes women to remain silent even if their unalienable rights are abused. Heer sounds like a rebellion when she asserts:

To me, my husband was my son's murderer. He was also my daughter's molester. A parasite nibbling on the Holy Book, he was Lucifer, holding me by the throat and driving me to sin every night. He was Bhai's destroyer, Amma Sain's tormentor, Ma's humbler and the people's exploiter. He was the rapist of orphans and the fiend that fed on the weak. But over and above all this, he was known to be the man closest to Allah, the one who could reach Him and save us. (32)

The portrayal of Heer's retelling about Pir Sain shows that he was a murderer and molester in a literal sense. Pir Sain had sexual intercourse with many women outside the marriage institution and killed the fetus if they got pregnant. Besides, he molested girls of his daughters' age and even illegitimate daughters by women who were working for him in his haveli(mansion). Although he claims to be closer to the Allah, he commits several social crimes. His religious hypocrisy becomes obvious when he cheats on innocent people who honor him.

The cognitive aspect of women reflects when Heer revolts against the religiondriven social system. She does have potentials to express her anger and aggression like that of male characters especially her husband, and her son. Their brutal behavior and domination persist over women because women remain silent as long as they can tolerate.They questionreligious books and the Shrine- symbol of religion. Heer suspects the entire institution that is unfair and partial. She questions to the Almighty why there is an injustice facing the helpless and poor. When she realizes her selfhood under threat, she commences to question the religious principles as well. She questions the position of her own son, Rajaji who does not treat her as mother. Rather he behaves with her as a woman. How a man treats with a woman is depicted as, "Rajaji stood over me and growled, "She is a curse. She gave our family nothing but shame. I pray she dies before she can sting us like snake again" (222). The relationship of Rajaji with Heer implies her subjugated position in the family. Even her own son does not treat with her respectfully. The men's dominant presence questions patriarchy that prioritizes males.

Rafia Hasan discusses theological roots of Pakistan and suggests that women's position in such a society would automatically become one of equality and emancipation, for "equality in the role and status of women in Islam has been ensured and dealt with comprehensively within a framework of rights and privileges in an Islamic society. While it is recognized that the two sexes have a certain natural division of functions, equality of fundamental human rights has been enjoined"(68). Hasan argues about the equalizing women's position as required for bettering social harmony. In spite of the detailed legal 
guidelines for women's rights and privileges in an ideal Islamic civil society, any demand for those rights in Pakistan was "met with considerable opposition due to various sociological, economic, and political reasons. The forces of custom, orthodoxy, and reaction joining hands at times with colonial rulers did much to water down the rights of equality granted by Islam" (69). The presence of the British in the subcontinent further complicated the status of Muslim women by confining them to homes and conditioning them to accept the prescribed role-that of submissive wife, daughter or sister.

E. Jeffrey Popke, a poststructuralist critic asserts that the system of thought determines the meaning of cultural practices. He argues, "The apparent stability of meaning embedded in any system of thought is potentially destabilized by elided traces of difference, and by the multiple contexts in which knowledge is produced, received and interpreted" (300). The knowledge is produced in the cultural setting. As the culture is, so does the formation of meaning become. On a similar note, Heer's personality is formed in such a way that she cannot control her own life in patriarchy.

When discussing Heer's individuality, William Connolly's rethinking of subjectivity relevant. Connolly calls such an approach "ontotheological", implying that the foundations that thetheories rest on owe more to faith than to any demonstratable certainty about the "ultimate answer to the question of being" (71). In contrast, Connolly's focus is on the political implications of particular identities. In his view, identity is as essential as Butler's desire to wish the terms of one's recognition as a subject is. For Butler, subjectivity is necessary. However, this necessity takes on a somewhat negative connotation that looks more like unavoidable. In Butler's view, subjectivity itself is rather flexible. Butler's focus is directed at those spaces between subject-producing discourse and the concluding subjectivity produced by such discourse. It is within these spaces that she sees the possible for subverting discourse and redirecting power.Therefore, Butler positions her critical subjectivity as capable of taking advantage of the "fluidity of identities that suggests an openness to re-signification andrecontextualization" (338). With this in mind, one can imagine why Butler is skeptical of any endeavor to embrace a particular identity or subject position. Such an embrace would come at the foreclosure of other possibilities of being, and ultimately, such foreclosures for Butler are practices that would end the subversive possibility of re-signification. Therefore, for Butler, embracing any particular identity is equivalent to the adopting one ontological class of existence at the expense of another and thereby engendering segregation.

Hence, Butler's resistance to adopting any position that could be interpreted as foundational makes such speculation problematic. With Connolly, it is not only the general necessity of subjectivity that is imperative but also the affirmative recognition that it is 
"surely undesirable to be human without some sort of implication in a particular identity" (9). Not only is it necessary to be something, but something in particular-infact, somebody in particular. In Butler's world, there is this vague notion of subjective spirits proficient of action. In Connolly's, there are people with concrete identities that bring order to their worlds and organize the way that they act in these worlds. The same identities come into conflict as well.

The researcher argues that a perspective that refuses to assume any foundational premises on which significant selfhood can be established leads to a more ethical negotiation of difference by using the work of Judith Butler and William Connolly. The bridal and maternal identity of Heer is in crisis as Heer suffers exploitation and suppression in the haveliof her husband, Pir Sain. She cannot breathe into fresh air as long as her husband is alive. Durrani by carving her crystal picture in the text tries to assert the phenomenal reality of the time, "Amma Sain had been mistress of the Haveli for many years until I weaned away that burden. She had known everything and yet known little, or perhaps it was a feminine intelligence: she knew more than she let on" (13). Amma with the feminine attributes leads the family and pretends to have been enjoying her life in patriarchy. Heer focuseson her mother's innocent plight and tells much about the lives of women with feminine qualities. The narrator, Heer recalls her previous days and reflects upon the activities she has done. Asif Iftikhar says pertaining to the genuine plight of Heer in Blasphemy:

I don't think that the story is against Islamic society. It is simply against the exploitation of religious feelings and fears of ignorant people by clergymen (Pirs) who are thought to be close to god and have special power to help people. And I also don't think that the author tries to say that this is what Pakistan is all about.Because the author tells about the life styles of people both in the shrine and outside the shrine. (31)

Iftikhar favors the position and efforts of the writer in exposing fears of the ignorant people in Islam and thus says that Durrani is a sensible author who has been capable of envisioning the substantial problems and confusions created by the clergymen considered as the messengers of the Almighty. The hypocrisy embodied by the so-called religious and sacred people who carry on dual facets alters their veil of such facets for their stakes. Heer by characterizing and telling the interrelationship among the characters of both sexes male and female, asserts that patriarchy is not commendable in the process of developing individual identity. The way society looks at women is biased and unfair. People use two kinds of lenses for perceiving women and men. Asma Barlas states in her essay "Engaging Islamic Feminism: Provincializing Feminism as Master Narrative": 
For one thing, I am clear that the focal point of my resistance has never been the idea that women and men share in an indivisible and equal humanity; rather, the focal points of my resistance have had to do with some of the accoutrements of feminism. Then, too, I understand that Islamic feminism as Badran defines it is liberatory in the sense both of being inclusive and being based in notions of justice that cut across spurious and unproductive binaries and divisions. (22)

Barlas' objection shows the binaries deliberately practiced in patriarchy that implicitly empowers men to women. This division based on gender creates the ground for furthering the gap between men and women. The birth of female babies shocks and saddens family members since women are considered a curse and they do not respect the mother as well. There is not a lot of ceremony in the Islamic culture in Pakistan in that time. The contemporary society guided by patriarchy is presented. Heer says, "It is a caution against any form of dishonor that might befall our future generations from the hazardous actions of the female species-we women are known to be a curse,' she would say in one breath" (23). Women are equal to men in all aspects of being but the society creates such demarcation lines thatisolate women from men. After all, social values are male-oriented and are made for men. Men do not have to abide by such cultural norms, which do not favor them. Blasphemy reflects on the Islamic culture that is much biased and is in the favor of only males. The mother is supposed torearthe children. The father does not usually involve the bringing-up of children.

What a woman needs for life, is a big question if she is thinking. However, if she is barred from the thought process by the society she has been born in she sees everything through narrow prism. Heer is thinking and she questions the decision her mother made while choosing Heer's life partner. Heer suffers patriarchy and thus expresses her agony, "Ma had made a choice about the rest of my life" (25). A woman is not free in patriarchy throughout her life. Until she is a child, she depends on the decisions made for her by her parents; when she is grown and gets married, she lives for husband and then finally she is accustomed to living for her children. She completes a sort of ritual of playing distinct roles at different ages. Haifaa A. Jawad in The Rights of Women in Islam mentions:

Islam regards women to be equal to men as human beings; hence it emphasizes mutual understanding and respect between the two sexes. From the Islamic viewpoint, women as human beings and as half of the society should be treated with care, tenderness and affection. Indeed, the Prophet insisted on kind and gentle treatment of women and demonstrated this not only through his attitude towards his wives but also in his teachings to his followers. He constantly encouraged them to be kind, civil and considerate when dealing 
with women: 'The more civil and kind a Muslim is to his woman whether wife, daughter or sister the more perfect in faith he is' he declared. (22)

In Islam, women are equal to men. However, women are to be treated with care and delicacy as asked by the prophet implies that they are secondary with the object position in the society. Otherwise, they need no caring and rearing by their counterparts. The culture that respects material things more than the human beings is certainly uncivilized and irrational as portrayed in the novel.

\section{Conclusion}

Durrani implicitly passes a commentary over the Islamic rigid culture that cripples the position of women and encourages men to impose their authority over women. The most prominent thing in the life of a woman seems to be her husband and she expects to have a husband who can take care of her in all aspects of her life. She goes on obeying and doing everything to please him since her source of pleasure is the husband. The target of women's lives in general in patriarchy is to obtain love from their husbands. However, Durrani enriches her characters especially Heer with the power of protest against exploitation and oppression.

The paper infers that Muslim culture is responsible for the marginality of women as portrayed in the novel. Durrani by demonstrating the pathetic and painful scene of the women charactersrepresenting the married women of the time in Pakistan questions docile position of women in the Islamic culture. Unfortunately, they lose freedom to choose life of their dreams as exemplified in the case of Heer. She loses happiness and right to lead her life independently. The question of women's rights and status in Pakistan demonstrates the problems in the cultural and social setting of the Islamic culture. Durrani portrays Heer to question the Shrine with religious significance. Thus, the transformation of Heer's selfhood is the exploration of the research.

\section{Works Cited}

Barlas, Asma. Believing Women’ in Islam. University of Texas Press, 2002. Print.

Bulter, Judith. Gender Trouble: Feminism and the Subversion of Identity. Routledge, 1990. Print.

Connolly, William. Identity/Difference: Democratic Negotiations of Political Paradox. Cornell University Press, 1991. Print.

Durrani, Tehmina. Blasphemy. Ferozesons (Pvt.) Ltd., 1998. Print.

Hasan, Rafia. "The Role of Women as Agents of Change and Development in Pakistan". Human Rights Quarterly. 3.3 (August 1981): 68-75. Print.

Iftikhar H. Culture and Customs of Pakistan. Greenwood P, 2006. Print. Jawad, Haifaa A. The Rights of Women in Islam. Macmillan Press Ltd, 1998. Print.

Popke, E. Jeffrey."Poststructuralist Ethics: Subjectivity, Responsibility, and the Space of Community". Progress in Human Geography 27.3 (2003), pp. 298-316. Print. 